\title{
Experimental Investigation of a Pilot-Scale Concerning Ex-Situ Bioremediation of Petroleum Hydrocarbons Contaminated Soils
}

\author{
Valer Micle \\ Technical University of Cluj-Napoca \\ loana Sur ( $\square$ ioana.sur@imadd.utcluj.ro ) \\ Technical University of Cluj-Napoca
}

\section{Research Article}

Keywords: aeration, bioremediation, moisture, microorganism, petroleum hydrocarbons, soil.

Posted Date: March 3rd, 2021

DOI: https://doi.org/10.21203/rs.3.rs-257625/v1

License: (c) (i) This work is licensed under a Creative Commons Attribution 4.0 International License.

Read Full License 


\title{
1 Experimental investigation of a pilot-scale concerning ex-situ 2 bioremediation of petroleum hydrocarbons contaminated soils
}

3

4

5

\author{
Valer Micle $^{1} \cdot$ Ioana Monica Sur ${ }^{*}$ \\ ${ }^{1}$ Technical University of Cluj-Napoca, Romania, Faculty of Materials and Environmental Engineering, \\ Department of Environment Engineering and Entrepreneurship of Sustainable Development, 103-105 Muncii
}

Avenue, 400641, Cluj-Napoca, Romania;

*corresponding author: ioana.sur@imadd.utcluj.ro

\begin{abstract}
The soil samples were taken from the site of a former oil products depot from an industrial area (Romania). The soil samples taken were analyzed from a physical and chemical point of view: texture, ph, soil micronutrient content, metals concentration and petroleum hydrocarbon concentration (PHCs). The soil contaminated with TPH $\left(4280 \mathrm{mgkg}^{-1}\right)$ was disposed in the form of a pile (LxWxH:3000x1400x500 mm). Experiments a pilot-scale were conducted over 12 weeks at constant $\mathrm{pH}(7.5-8)$, temperature $\left(22-32^{\circ} \mathrm{C}\right)$, nutrient contents $\mathrm{C} / \mathrm{N} / \mathrm{P}$ ratio 100:10:1, soil aeration time (8 hour/day) and moisture (30\%). Samples were taken every two weeks for the monitoring of the TPH and the microorganisms content. During experiment every two weeks were added microoganisms (Pseudomonas and Bacillus). Results of the analyzes regarding the concentration of PHCs were revelead a linear decrease of the concentration of PHCs after only two weeks of treatment. This decrease in concentration was also achieved in the following weeks. Following the analysis performed on the model at the pilot scale regarding the depollution process, it can be concluded that a soil contaminated with petroleum hydrocarbons can be efficiently depolluted by performing an aeration of $8 \mathrm{~h} /$ day, adding microorganisms Pseudomonas and Bacillus to ensure the conditions for increasing in the total number of germs (colony forming units-CFU) from $151 \times 10^{5}$ to $213 \times 10^{7}$ CFU/gram of soil, after 12 weeks of soil treatment - the depollution efficiency achieved is $83 \%$.
\end{abstract}

Keywords: aeration, bioremediation, moisture, microorganism, petroleum hydrocarbons, soil.

\section{Introduction}

Currently, petroleum (oil) is the main energy source in the world ${ }^{1}$. Saturated hydrocarbons are the main components of natural gases and oil ${ }^{2}$. Petroleum hydrocarbons are natural chemical substances used by humans for many activities, being a complex mixture of a wide range of chemicals found in crude oil and refined products ${ }^{1,3}$.

The development of the oil industry is sometimes accompanied by the appearance of certain side effects, as it pollutes the environment and affects the health of the human population ${ }^{4}$. Environmental pollution with PHC through leaks and spills taking place during production, storage and transport of oil causes water and soil pollution, affecting the safety of ecosystems and human health, thus becoming a global environmental problem ${ }^{5,6}$. The most disastrous effects occur when crude oil doses exceed $200 \mathrm{~g} / \mathrm{kg}$ of soil ${ }^{7}$.

Studies have shown that bioremediation is a safer and less expensive method for removing dangerous contaminants and producing secondary non-toxic substances ${ }^{8}$. Interest for polluted soil and water bioremediation has increased over the past thirty years ${ }^{9}$, primarily due to the fact that bioremediation is based on the ability of some microorganisms (bacteria, fungi) to degrade organic matter and allow the acceleration of natural decomposition of organic pollutants ${ }^{10,11,12}$. The success of bioremediation depends on a series of factors: the affected area, type, amount and concentration of pollutants, soil $\mathrm{pH}$, ambient temperature, soil moisture, amount of nutrients, type and amount of microorganisms and oxygen availability, available time and financial resources ${ }^{13,14}$. Bioremediation has several disadvantages: it requires long remediation time, it is climate dependent and its effect is not fully elucidated ${ }^{15,16,17,18}$.

The biopile method can be used for decontamination of soil polluted with $83 \%$ aromatic polycyclic hydrocarbons - nine months of treatment, and for the decontamination of a soil polluted with $60-73 \%$ mineral oils after seven months of treatment ${ }^{19}$.To achieve a maximum level of biodegradation by using the biopile method, the aeration and irrigation systems' designs are important ${ }^{20}$. Natural and forced aeration (blowing or extracting air 
through pipes) can be introduced to improve soil ventilation in order to assure the oxygen supply needed for the bio-reactions taking place in the pile of polluted soil ${ }^{21}$.

In order to evaluate the use of the biopile method in bioremediation of soils polluted with oil, Iturbe et colab. conducted several studies: 1) in a former station of storage and distribution of oil, after 66 days of treatment they achieved a remediation efficiency of $85.2 \%{ }^{22} ; 2$ ) at an oil plant in northern Mexico, after 22 weeks of treatment they achieved a remediation efficiency of $80 \%{ }^{23}$.

In a study conducted on soil contaminated with hydrocarbons (2000, 4000 and $\left.6000 \mathrm{mgkg}^{-1}\right)$, three biopile piles of $0.6 \mathrm{~m}^{3}$ were made, they were bio-stimulated with nutritive substances and aerated, obtaining an efficiency of $66-75 \% \%^{24}$.

Gogoi et al. (2003) depolluted soil contaminated with HTP (44.000 $\left.\mathrm{mgkg}^{-1}\right)$. Soil was placed in cells (500 kg of soil/cell), amended with nutrients and inoculated with a microbial consortium isolated from hydrocarboncontaminated soils. The system was aerated one hour per day at a rate of $100 \mathrm{~m}^{3} / \mathrm{h}$. At the end of the 365 days of operation, remediation in the cells was $75 \%$ with a degradation rate of $90 \mathrm{mgkg}^{-1} / \mathrm{day}^{25}$.

Studies have shown that using indigenous microbial strains is preferred in bioremediation processes ${ }^{26,27}$, and adding nutritive substances may increase the efficiency of removal ${ }^{28,29}$.

Chemlal et al. (2012) conducted a study in which they achieved a removal efficiency of diesel fuel of $70 \%$ in 40 days using a pre-adapted consortium, together with nutrient growth (urea as nitrogen source and $\mathrm{K}_{2} \mathrm{HPO}_{4}$ as phosphorus source), maintaining moisture content (15-25\%) and aeration ${ }^{30}$.

$\mathrm{Wu}$ et al. (2016) compared treatments with biodisposition and biostimulation achieving a degradation of $60 \%$ of PHC by adjusting soil C:N:P to 100:10:1 at a water content of $20 \%$, and a degradation of $34 \%$ by adding Acinetobacter SZ-1 to the soil after 10 weeks of treatment ${ }^{31}$.

A pilot scale bioremediation study of soil contaminated with PHC from a sub-arctic site indicated that aeration and moisture addition were sufficient to obtain efficient biodegradation, while supplementation of nitrogen did not influence the efficiency of biodegradation ${ }^{32}$.

Hernández-Espriú et al. (2013) research has demonstrated the applicability of natural gums as soil remediation enhancers in diesel-contaminated systems. Ionic surfactants showed removal rates above the control test of about 78.51\% (Maranil LAB), 71.27\% (Texapon 40), 60.13\% (SDS), and 48.19\% (Surfacpol G) and Guar gum and locust bean gum showed efficiencies of $54.38 \%$ and $53.46 \%$, respectively. An $82 \%$ TPH-diesel removal rate was achieved for a very low gum concentration $(2 \mathrm{ppm})^{33}$.

Bioremediation is performed using specific strains of oil degradation: Rhodococcus with an efficiency of up to $55-59 \%$ in the case of crude petroleum hydrocarbons ${ }^{34}$.

O'Brien and colleagues aimed at degradation the natural degradation of petroleum hydrocarbons (PHC) from soils contaminated Bakken crude oil (western North Dakota, USA). Initial concentrations of PHC, 1400, 700, 220 and $100 \mathrm{mgkg}^{-1}$ ). After two seasons of growth under crop management Wheat (Triticum aestivum L.) and field peas (Pisum sativum L.), PHC concentrations were reduced between 46 and 53\%. Continuing a normal crop rotation can be a viable management strategy for low-level soil contamination ${ }^{35}$.

In a study performed by Baoune et al. it was pointed out that microorganisms of the type Streptomyces sp. Hlhl removed total petroleum hydrocarbons (TPH), they obtained a yield of $40 \%$ at an initial concentration of $10 \%$ and $55 \%$ at an initial concentration of $2 \%$, respectively ${ }^{36}$.

The removal of total petroleum hydrocarbons (TPH) can be achieved in 112 days by using a bacterial consortium (bioaugmenatation): $82.6 \%$ and by adding endogenous earthworms (Pontoscolex corethrurus) the yield increases $(86.4 \%)^{37}$.

Starting from the results obtained previously through experiments at laboratory level ${ }^{38}$, the objective of the study was to determine the yield of the ex-situ bioremediation process of soils contaminated with PHC using a pilot scale treatment set that controls soil aeration duration, moisture and microorganism content.

\section{Materials and methods}

\subsection{Soil sample investigation}

In order to carry out the pilot scale experiment, soil was collected from the site of a former warehouse of petroleum products from an industrial area (Romania). The taken soil samples were transported into the laboratory where the stones and roots were removed and the soil was mixed to ensure homogeneity of the sample. Soil thus prepared (samples P1, P2 and P3) was quantitatively and qualitatively analyzed:

- The soil's texture was determined using a gravimetric method; 
- The soil $\mathrm{pH}$ was determined in $1 / 2.5(\mathrm{w} / \mathrm{v})$ soil/water extract using a HANNA pH-meter;

- Nitrogen was determined by Kjeldhal ${ }^{39}$;

- For determining total potassium and phosphorus content $3 \mathrm{~g}$ of soil with $100 \mu \mathrm{m}$ granulation was used over which was added $7 \mathrm{~mL}$ of $12 \mathrm{M} \mathrm{HCl}$ and $21 \mathrm{~mL}$ of $15.8 \mathrm{M} \mathrm{HNO}_{3}$ and the mixture was refluxed for 2 hours, filtered and diluted up to $100 \mathrm{~mL}$ with $2 \%$ (v/v) $\mathrm{HNO}_{3}{ }^{40}$;

- Mobile phosphorus and potassium were determined by ICP-OES after extraction of $5 \mathrm{~g}$ soil in $100 \mathrm{ml}$ ammonium acetate-lactate mixture $(\mathrm{pH}=3.75)$ for 4 hours according to Egnèr-Riehm-Domingo method;

- The organic carbon was determined by Walkley-Black method by oxidising the organic matter from $0.2 \mathrm{~g}$ soil with $5-10 \mathrm{ml}$ of $1.6 \%(\mathrm{w} / \mathrm{v})$ sulfochromic mixture on a hot plate for $20 \mathrm{~min}$. The excess of chromic acid was titrated with $0.2 \mathrm{~mol} \mathrm{~L}^{-1} \mathrm{Mohr}$ salt solution in the presence of diphenylamine as an indicator;

- Heavy metals concentration of the collected soil sample was determined through Atomic Absorption Spectrometry (AAS) using a SHIMADZU AA-6800 spectrometer. For determining heavy metals concentration $3 \mathrm{~g}$ of soil with $200 \mu \mathrm{m}$ granulation was used over which was added $7 \mathrm{~mL}$ of $12 \mathrm{M} \mathrm{HCl}$ and $21 \mathrm{~mL}$ of $15.8 \mathrm{M}$ $\mathrm{HNO}_{3}$ and the mixture was mineralized for 3 hours, filtered and diluted up to $100 \mathrm{~mL}$;

- Hydrophysical indices: withering coefficient, field capacity and useful capacity were determined taking into account soil moisture that was determined by the gravimetric method $^{39,41}$;

- The PHC content was determined by Fourier Transformed infrared spectroscopy (FTIR) ${ }^{5}$. The dry soil (5-10 g) was subjected to 2 consecutive extractions with $20 \mathrm{~mL}$ tetrachlorethylene (TCE) for 30 minutes/extraction. After extraction, the supernatant was separated and the soil residue. Polar compounds (water, vegetable oils and animal fats) was removed applied by passing the extract through a $10 \mathrm{~cm}$ long and $0.6 \mathrm{~cm}$ with column packed with $0.150-0.250 \mathrm{~mm}$ grain-size magnesium silicate for column chromatography (Florisil). The purified extract was made up to $50 \mathrm{~mL}$ with TCE. The FTIR spectrum of the purified extract was recorded between 3150-2750 $\mathrm{cm}^{-1}$ at $4 \mathrm{~cm}^{-1}$ resolution in $10 \mathrm{~mm}$ optical path-length quartz cells by a Spectrum BX II (Perkin Elmer) spectrometer equipped with DTGS detector. The measured absorbance at $2925 \mathrm{~cm}^{-1}$ attributed to $\mathrm{CH}_{2}$ - group was converted to TPH using the linear regression model. The TPH content of soil was calculated according to equation ${ }^{5}$ :

Where: $C$-is the concentration of TPH in soil $\left(\mathrm{mgkg}^{-1}\right) ; c$-is the concentration of TPH in the extract $\left(\mathrm{mgmL}^{-1}\right)$, $D_{f}$ is the dilution factor; $C_{f}$ is the concentration factor; $V$ is the volume of the extract $(\mathrm{mL}) ; w$ is the weight of the sample $(\mathrm{kg})$.

\subsection{Isolation of indigenous microorganisms}

The indigenous microorganisms was isolated from the test soil and grown on GPS culture media prepared from sodium L-glutamate-10 $\mathrm{gL}^{-1}$, starch soluble $-20 \mathrm{gL}^{-1}$, potassium dehydrogenate phosphate- $2 \mathrm{gL}^{-1}$, magnesium sulfate- $0.5 \mathrm{gL}^{-1}$, phenol red- $0.36 \mathrm{gL}^{-1}$ and agar- $-12 \mathrm{gL}^{-1}$. The isolated strains were stored and multiplied in a nutrient broth: meat extract $-10 \mathrm{gL}^{-1}$, peptone $-10 \mathrm{gL}^{-1} ; \mathrm{NaCl}-5 \mathrm{gL}^{-138}$.

Bacterial strains were incubated and shaken $(120 \mathrm{rpm})$ at $25^{\circ} \mathrm{C}$ for $24 \mathrm{~h}$. Inoculation was made with $100 \mu \mathrm{L}$ of culture from liquid culture medium. The development of microorganisms was observed at $600 \mathrm{~nm}$ were using a UV spectrophotometer (Lambda 25, Perkin-Elmer). These cultures were morphologically and tinctorially characterized using the Gram staining technique ${ }^{38}$.

The amount of soil microflora in the samples taken from the experimental groups was established by the numerical determination of the microorganisms existent in the PHC polluted soils. For the numerical determination of microorganisms existing in the soil, decimal dilutions (saline solution) were made. Incubation was done at $30{ }^{\circ} \mathrm{C}$ for 48-72 $\mathrm{h}$. The assessment of the total aerobic microflora is made from plates having 30-300 colonies. The average of the three plates was corrected with the dilution factor to obtain the colony-forming unit UFC g ${ }^{-1}$ soil $^{38}$. 


\subsection{Pilot scale experimental investigation}

Soil polluted with petroleum hydrocarbons (4000 kg), after sorting and homogenization was added the microorganisms and placed in a pile (Lxlxh: 3000x1400x500 mm) in order to be subjected to the proposed experiments (fig. 1). The pile of soil was placed on an impermeable surface consisting of a concrete platform over which plastic foil was added. At the bottom of the pile was placed a drainage layer made of gravel with a 4-7 mm diameter, which favors the aeration process. In this layer of gravel was introduced a part of the pipe system through which aeration and wetting are carried out.

The system for introducing water and the nutrients and microorganisms solution (Pseudomonas and Bacillus) consists of a tank with a capacity of $100 \mathrm{~L}$, a self-priming pump with a flow of $50 \mathrm{~L} / \mathrm{min}$, corrugated absorption and discharge hoses and a blower. The discharge hose is connected to the distribution network that consists of an $\varnothing 180 \mathrm{~mm}$ PVC pipe branched into 5 perforated $\varnothing 50 \mathrm{~mm}$ PVC pipes placed horizontally in the middle of the pile.

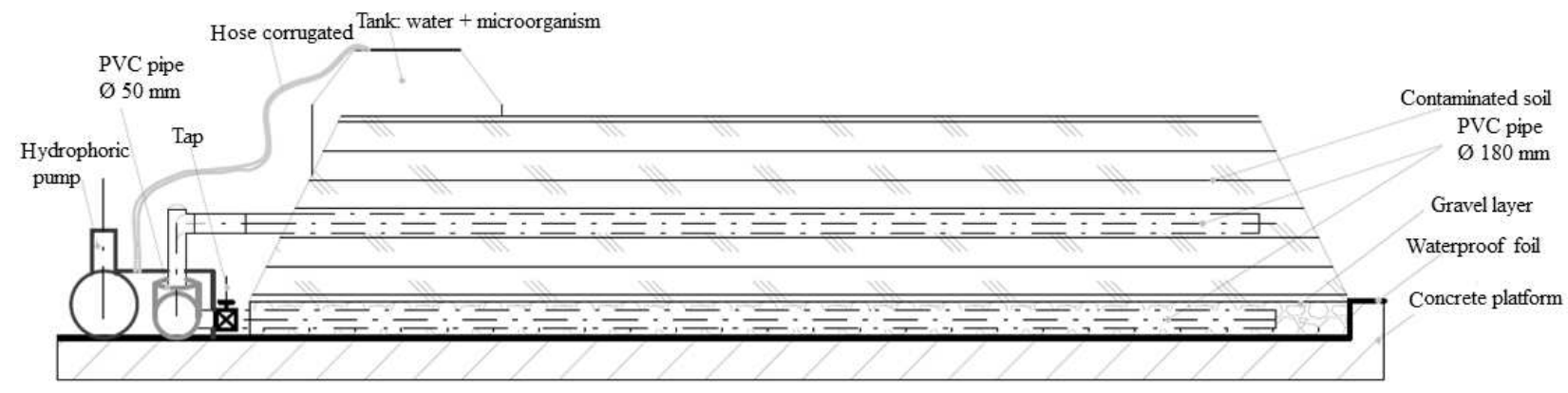

Fig. 1 Pilot scale experiment

Research carried out at pilot scale level lasted 12 weeks at the following parameters: $30 \%$ moisture, a temperature of $20-32^{\circ} \mathrm{C}$, $\mathrm{pH}$ of $7.5-8,8 \mathrm{~h}$ /day aeration duration.

Soil moisture was manually achieved by sprinkling through the top of the biopile cell and through the water supply system inside of the pile, aiming for field capacity moisture of $30 \%$. Moisture was monitored throughout the experiment.

The temperature at which the pilot scale experiment was carried out was between $25-32^{\circ} \mathrm{C}$. Temperature was measured and monitored throughout the experiment with the WTW Multiline IDS-3430 Multiparameter meter.

Soil $\mathbf{p H}$ was monitored weekly using the HI 3512-02 pH meter.

Soil aeration was achieved through the aeration system consisting of a blower and an air distribution network. The air distribution network consists of 5 perforated PVC pipes with a diameter of $50 \mathrm{~mm}$ each. These pipes are distributed inside the pile of soil as follows: three pipes are placed horizontally in the gravel layer at the base of the pile and two pipes are placed in the middle of the pile in order to ensure uniform aeration of the soil. Aeration was performed for 8 hours a day throughout the experiment ( 12 weeks) by means of the blower, having a flow of $10 \mathrm{~m}^{3} \mathrm{~min}^{-1}$.

Quantity of microorganisms. Microorganisms used for bioremediation were isolated from the native micro flora of the polluted soil and grown in the laboratory on culture media.

When making the soil pile for the experiment, after placing each layer of soil with a thickness of $10 \mathrm{~cm}$, a manual sprinkling of the soil was carried out with a solution loaded with microorganisms - a total quantity of $9 \mathrm{~L}$ with a concentration of $94 \times 10^{3} \mathrm{CFU}$. Throughout the experiment microorganisms were added once every 2 weeks (weeks $2,4,6,8,10$ ) by means of the perforated pipes inside the pile of soil - the quantity of $9 \mathrm{~L}$ with a concentration of $94 \times 10^{3} \mathrm{CFU}$ and by manual sprinkling through the upper part of the pile of soil.

Soil sampling. Before adding the microorganism loaded solution, soil samples were taken from the pile of soil every 2 weeks (weeks $2,4,6,8,10,12)$ in order to determine the hydrocarbon concentration $(150 \mathrm{~g}$ of soil/sample) and to determine the total number of germs (50 g of soil / sample). The determination of the number of microorganisms present in the biopile cell during the experiment can be done according to point 2.2 . 
Soil samples were taken from 3 points at different depths, according to the diagram in figure 2, with a total of 9 soil samples being taken every week. These soil samples were coded according to their location, sampling depth and week in which they were taken (Table 1).

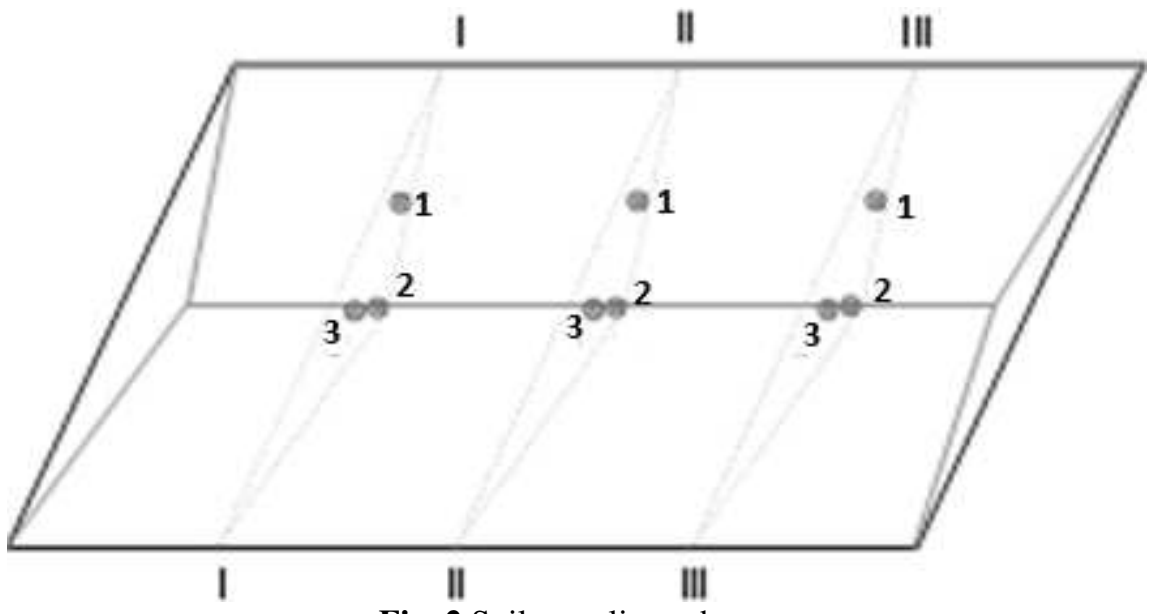

Fig. 2 Soil sampling scheme

Table 1 The code of soil samples according to their sampling location and depth

\begin{tabular}{|c|c|c|}
\hline The sampling section & Sampling depth & The code \\
\hline \multirow{3}{*}{ I-I } & Sample $1: 0-5 \mathrm{~cm}$ & I.1 \\
\cline { 2 - 3 } & Sample 2: $15-25 \mathrm{~cm}$ & I.2 \\
\cline { 2 - 3 } & Sample $3: 25-35 \mathrm{~cm}$ & I.3 \\
\hline \multirow{3}{*}{ II-II } & Sample $1: 0-5 \mathrm{~cm}$ & II.1 \\
\cline { 2 - 3 } & Sample 2: $15-25 \mathrm{~cm}$ & II.2 \\
\cline { 2 - 3 } & Sample 3: $25-35 \mathrm{~cm}$ & II.3 \\
\hline \multirow{3}{*}{ III-III } & Sample $1: 0-5 \mathrm{~cm}$ & III.1 \\
\cline { 2 - 3 } & Sample 2: $15-25 \mathrm{~cm}$ & III.2 \\
\cline { 2 - 3 } & Sample 3: $25-35 \mathrm{~cm}$ & III.3 \\
\cline { 2 - 3 }
\end{tabular}

\subsection{The evaluation of the effectiveness}

The evaluation of the effectiveness of the depollution process was performed by determining the yield for each sample with the following Eq. ${ }^{42}$ :

$$
\eta=\frac{C_{i}-C_{f}}{C_{i}} 100[\%]
$$

In which: $\eta$ is the yield, in $\%$;

$\mathrm{C}_{f}-\mathrm{PHC}$ concentration in soil at the end of the treatment time, in $\mathrm{mgkg}^{-1}$;

$C_{i}$-initial PHC concentration of soil, in $\mathrm{mgkg}^{-1}$.

\section{Results and discutions}

\subsection{Soil samples investigation}

The soil was classified as clay medium (LL): $41.6 \%$ clay, $17.59 \%$ silt, $18.7 \%$ fine sand and $22.1 \%$ coarse sand according to the USDA classification.

The test soil has a weak basic reaction $(\mathrm{pH}=7.5 \pm 0.5)$, a content of $2.34 \%$ total organic carbon and $0.126 \%$ total nitrogen. The investigated soil has a moderate humus content $(4 \%)$. A high content of potassium $\left(\mathrm{K}_{\mathrm{AL}}=272 \mathrm{mgkg}-\right.$ $\left.{ }^{1}\right)$ and soluble phosphorus $\left(\mathrm{P}_{\mathrm{AL}}=19.2 \mathrm{mg} \mathrm{kg}^{-1}\right)$ has been registered.

The concentration of $\mathrm{Cu}\left(28.1 \mathrm{mgkg}^{-1}\right), \mathrm{Ni}\left(33.5 \mathrm{mgkg}^{-1}\right)$ and $\mathrm{Pb}\left(76 \mathrm{mgkg}^{-1}\right)$, exceeds the normal value (20 $\mathrm{mgkg}^{-1}$ ), according to the Romanian legislation (Order $\left.756 / 1997\right)^{43}$, being below the alert threshold. The 
concentration of $\mathrm{Zn}\left(174.6 \mathrm{mgkg}^{-1}\right)$ exceeds the normal value $\left(100 \mathrm{mgkg}^{-1}\right)$. The Manganese level found in the analyzed soil $\left(698 \mathrm{mgkg}^{-1}\right)$ presents lower concentrations compared to the normal value $\left(900 \mathrm{mgkg}^{-1}\right)$.

The investigated soil has the average field capacity $(25.5 \% \mathrm{~g} / \mathrm{g})$ that is used together with the withering coefficient $(13 \% \mathrm{~g} / \mathrm{g})$ and the useful capacity $(15.5 \% \mathrm{~g} / \mathrm{g})$ in order to establish the minimum moisture threshold required for depollution.

The average concentration of PHC in the tested soil was of $4280 \pm 400 \mathrm{mgkg}^{-1}$. This value was considered the initial content of PHC for the amount of TPH in the pile of soil. The initial concentration of PHC exceeded more than 2 times the intervention threshold for less sensitive soil uses $\left(2000 \mathrm{mgkg}^{-1}\right)$ established by Romanian legislation (Order no. 756/1997) ${ }^{43}$, thus requiring remediation.

\subsection{Isolation of indigenous microorganisms}

In the test soil two bacterial strains with bioremediation potential were isolated using a selective enrichment technique. These cultures are from genus Pseudomonas sp. and Bacillus sp. ( $1 \mathrm{~mL}$ solution contains $94 \times 10^{3} \mathrm{CFU}$ ), it two bacterial genus are commonly found in soil.

\subsection{Pilot scale experiment investigation}

\subsubsection{PHC concentration}

Results on the evolution of hydrocarbon concentration in the soil samples taken during experiments were subjected to an analysis in order to highlight the influence of treatment duration and to determine the efficiency of the bioremediation process.

In figure 3 is presented the evolution of PHC concentration in the 9 soil samples taken from the pile of soil throughout the experiment depending on the sampling section (I-I; II-II; III-III) during the experiment (12 weeks).

Analyzing figure 3 we observe a pronounced and linear decrease of the PHC concentration in the first 4 weeks for all the 3 sections, regardless of the sampling depth (1; 2 and 3). In the case of section I-I (fig. 3a) the PHC concentration from sample 1 continues with a sharp decrease being followed by stability and starting from week 8 the concentrations have a pronounced decrease. In sample 2 we can observe the same tendency starting with week 8 and the PHC concentration by the end of the experiment $\left(680 \mathrm{mgkg}^{-1}\right)$ is similar to the one in sample 1 $\left(610 \mathrm{mgkg}^{-1}\right)$, while sample 3 has slightly higher concentrations $\left(1300 \mathrm{mgkg}^{-1}\right)$.

In section II-II we can observe a continuous and linear decrease for sample 1 throughout the experiment, while samples 2 and 3 show an increase in week 6 and 8 respectively, after which a linear decrease is recorded until the end of the research period, PHC concentrations reaching around $680-1100 \mathrm{mgkg}^{-1}$.

Section III-III shows a decrease in the PHC concentration $\left(250-710 \mathrm{mgkg}^{-1}\right)$. Several stability areas can be observed: sample 3 (weeks 2-4), sample 2 (weeks 4-6) and sample 1 (weeks 6-8), followed by a significant increase (samples 2 and 3 ) in week 8 , except for sample 1 which decreases after the stability period to a value of $250 \mathrm{mgkg}^{-1}$. After the increase from week 8, samples 2 and 3 show a decrease until the end of the research period (410 $\mathrm{mkg}^{-1}$ and $710 \mathrm{mgkg}^{-1}$ respectively).

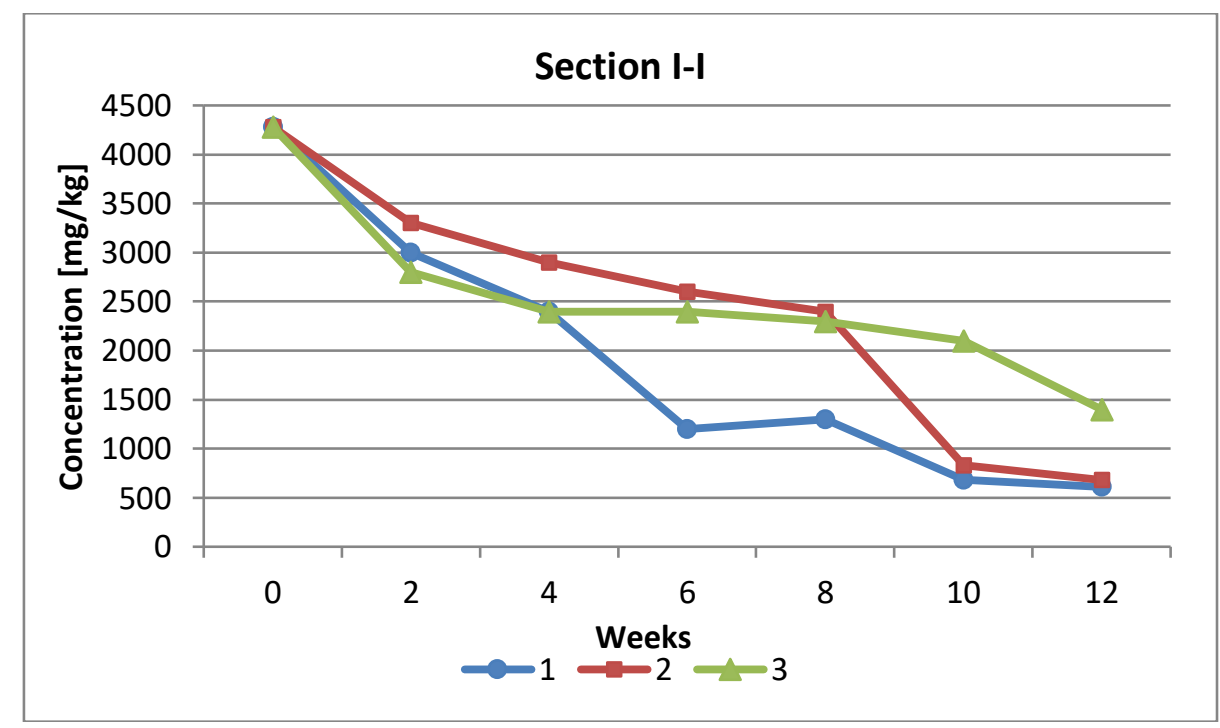


a)

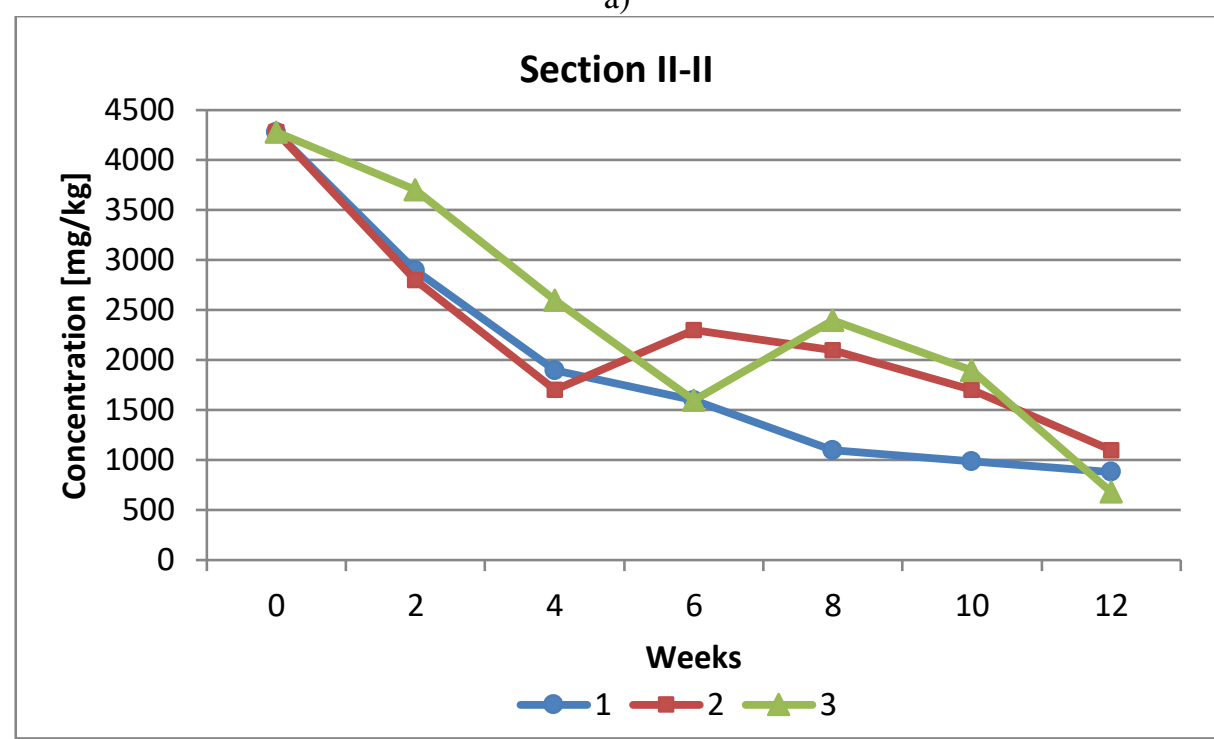

b)

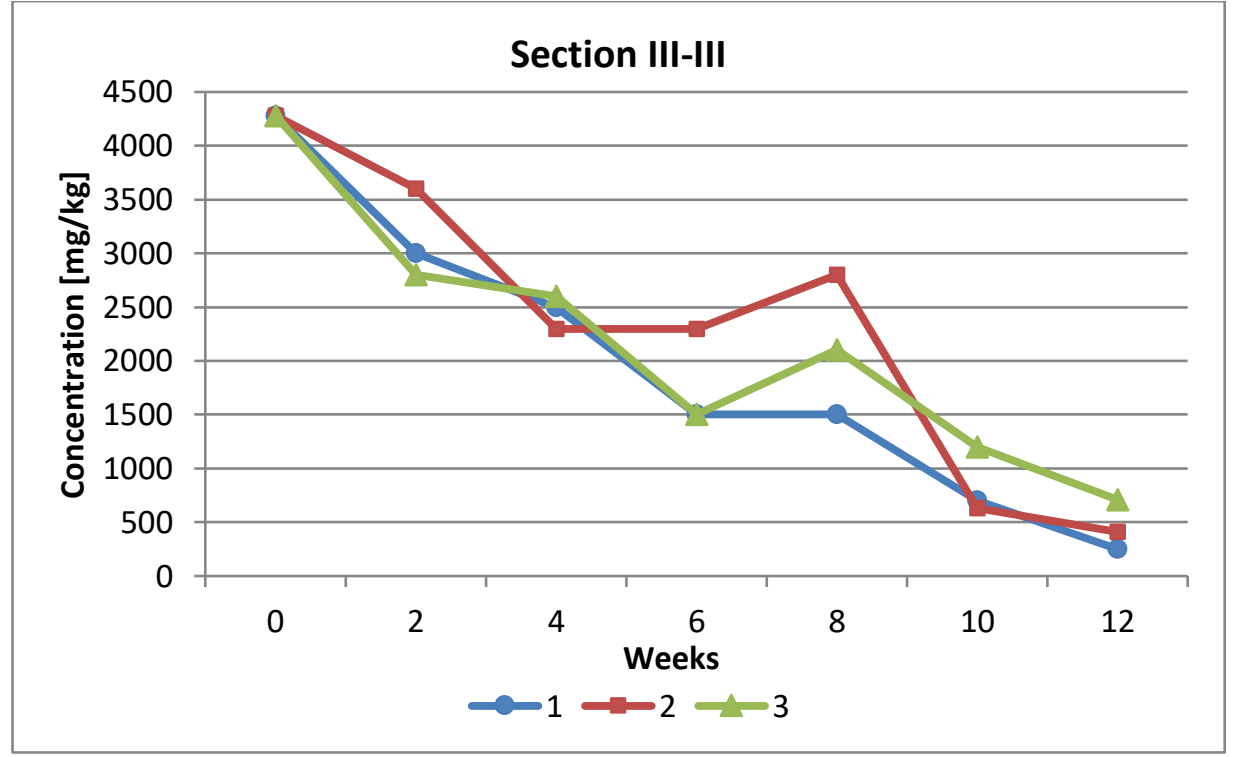

c)

Fig. 3 PHC concentration depending on time and section:

a) section I-I; b) section II-II; c) section III-III

Analyzing figure 3 a linear decrease can be observed for all 9 soil samples. All samples show a pronounced decrease in the PHC concentration after only two weeks of treatment, regardless of sampling point or depth. This decrease of concentration continues but the amount of TPH extracted from the soil is much lower as of week 4. At the end of the experimentation period ( 12 weeks) it can be observed that the value of the concentration of pollutant decreased below $1000 \mathrm{mgkg}^{-1}$, except for samples I.3 and II.2.

Concerning the concentration of PHC (fig. 3a) in the 3 sampling sections (I, II, III), a linear decrease can be observed throughout the experiment and more pronounced after only 2 weeks. In week 2 the concentrations are close in all the 3 sampling sections, lower concentrations can be observed for section II in weeks 4 and 8 of experiments, and in weeks 6 and 10 they are higher compared to section I and section III. The value of the PHC concentration decreases, being under $1000 \mathrm{mgkg}^{-1}$ in week 12 in the 3 sections at sampling points, the lowest value being in section III $\left(250 \mathrm{mgkg}^{-1}\right)$.

Concernig the concentration of PHC (fig. 3b) in the 3 sampling sections, a linear decrease of the pollutant concentration can be observed throughout the experiment. Section II shows lower values compared to sections I and III in weeks 2, 4 and 8 of experiments. Towards the end of the testing period (week 10) the PHC concentration in section II is much higher than in section I and in section III, where the concentration is similar. In the last week 
there is a stability in section I and a decrease in sections II and III. The lowest concentration is reached in week 12 in section III $\left(250 \mathrm{mgkg}^{-1}\right)$.

PHC concentration (fig. 3c) is decreasing during the experiment. In week 2 the concentration of pollutant in section II is much higher than in sections I and III. In weeks 4 and 8 in all 3 sections the concentration has approximately the same value. Low values can be observed at the end of the experiment in section II (680 $\mathrm{mgkg}^{-}$ $\left.{ }^{1}\right)$ and section III (710 $\left.\mathrm{mgkg}^{-1}\right)$, except for section I (1400 $\left.\mathrm{mgkg}^{-1}\right)$.

Analyzing from the treatment duration point of view a linear decrease for all the 3 sampling sections can be observed. All samples show a pronounced decrease in the concentration of PHC after only two weeks of treatment, regardless of the depth at which research is carried out. This decrease in concentration is also achieved in the following weeks, but the amount of TPH extracted from the soil is much lower starting from week 4 . At the end of the treatment period values under $1000 \mathrm{mgkg}^{-1}$ were registered.

Following analyses on the concentration of PHCs, a linear decrease of the $\mathrm{PCH}$ concentration was revealed after only two weeks of treatment. This decrease in concentration is also achieved in the following weeks, but the amount of TPH extracted from the soil is much lower starting from week 4 and week 6 of treatment, respectively.

Results obtained at the pilot scale level are similar to those obtained in the preliminary study at laboratory scale level ${ }^{38}$, with a pronounced decrease in the first weeks of treatment followed by a much slower decrease in the concentration of PHC.

\subsubsection{Quantity of microorganisms}

When the selected microorganisms are added to the soil on the soil to the experiment, an increase in the total number of germs (NTG) is observed independent of the sampling place (table 2). Concentration of microorganisms in the second week had values between $102 \times 10^{5}-209 \times 10^{5} \mathrm{CFU} / \mathrm{g}$ of soil, followed by an increase in weeks 4 and $6\left(106 \times 10^{5}-298 \times 10^{6} \mathrm{CFU} / \mathrm{g}\right.$ of soil). This growth trend is also observed in the following weeks, but after week 8 they are not so significant $\left(127 \times 10^{7}-238 \times 10^{7} \mathrm{CFU} / \mathrm{g}\right.$ of soil).

Table 2 Determination of total microflora during the experimental development stage

\begin{tabular}{|c|c|c|c|c|c|c|c|c|c|}
\hline \multicolumn{9}{|c|}{ Total number of germs (NTG) } \\
\hline \multirow{2}{*}{ Week } & $\mathbf{3}$ SECTION I-I & \multicolumn{3}{c|}{ SECTION II-II } & \multicolumn{2}{c|}{ SECTION III-III } \\
\cline { 2 - 9 } & $\mathbf{1}$ & $\mathbf{2}$ & $\mathbf{3}$ & $\mathbf{1}$ & $\mathbf{2}$ & $\mathbf{3}$ & $\mathbf{1}$ & $\mathbf{2}$ & $\mathbf{3}$ \\
\hline 0 & $94 \times 10^{3}$ & $94 \times 10^{3}$ & $94 \times 10^{3}$ & $94 \times 10^{3}$ & $94 \times 10^{3}$ & $94 \times 10^{3}$ & $94 \times 10^{3}$ & $94 \times 10^{3}$ & $94 \times 10^{3}$ \\
\hline 2 & $144 \times 10^{5}$ & $175 \times 10^{5}$ & $126 \times 10^{5}$ & $160 \times 10^{5}$ & $121 \times 10^{5}$ & $102 \times 10^{5}$ & $209 \times 10^{5}$ & $184 \times 10^{5}$ & $142 \times 10^{5}$ \\
\hline 4 & $125 \times 10^{6}$ & $127 \times 10^{6}$ & $106 \times 10^{6}$ & $158 \times 10^{6}$ & $176 \times 10^{6}$ & $85 \times 10^{6}$ & $183 \times 10^{6}$ & $162 \times 10^{6}$ & $199 \times 10^{6}$ \\
\hline 6 & $206 \times 10^{6}$ & $198 \times 10^{6}$ & $238 \times 10^{6}$ & $208 \times 10^{6}$ & $188 \times 10^{6}$ & $124 \times 10^{6}$ & $274 \times 10^{6}$ & $235 \times 10^{6}$ & $298 \times 10^{6}$ \\
\hline 8 & $168 \times 10^{7}$ & $144 \times 10^{7}$ & $159 \times 10^{7}$ & $131 \times 10^{7}$ & $127 \times 10^{7}$ & $147 \times 10^{7}$ & $158 \times 10^{7}$ & $141 \times 10^{7}$ & $133 \times 10^{7}$ \\
\hline 10 & $170 \times 10^{7}$ & $130 \times 10^{7}$ & $144 \times 10^{7}$ & $165 \times 10^{7}$ & $165 \times 10^{7}$ & $207 \times 10^{7}$ & $171 \times 10^{7}$ & $162 \times 10^{7}$ & $153 \times 10^{7}$ \\
\hline 12 & $201 \times 10^{7}$ & $185 \times 10^{7}$ & $190 \times 10^{7}$ & $226 \times 10^{7}$ & $238 \times 10^{7}$ & $259 \times 10^{7}$ & $219 \times 10^{7}$ & $199 \times 10^{7}$ & $197 \times 10^{7}$ \\
\hline
\end{tabular}

Analyzing the evolution of the number of microorganisms during the ex situ bioremediation process, a significant increase can be observed in the 3 sections. This is due to the fact that once every 2 weeks a new amount of microorganisms was added, but also to the fact that they have the optimal conditions for their development were ensured: soil aeration and temperature.

\subsection{The evaluation of the effectiveness}

Analyzing figure 4 it can be observed that the depollution efficiency is high, reaching $94 \%$ for sample III. 1 . The lowest efficiency is registered for sample I.3 (67\%) and the rest of the samples have efficiency around $80 \%$.

Compared to the results obtained in the preliminary study carried out at a laboratory scale level ${ }^{38}$ which highlighted the possibility of obtaining high efficiencies (56-76\%), the treatment period being 18 weeks on soil containing $7600 \pm 400 \mathrm{mgkg}^{-1}$ petroleum hydrocarbons, results of pilot scale experiments carried out under slightly different conditions indicate a reduction in the PHC concentration (64-94\%) in only 12 weeks. These results were partially validated by submitting a patent application ${ }^{44}$ to the Official Bulletin of Industrial Property (OSIM). It may also be mentioned that the obtained yields are comparable with yields obtained in other research conducted with similar treatment conditions: $80-85.2 \%{ }^{23}$ and $66-75 \%{ }^{24}$. 


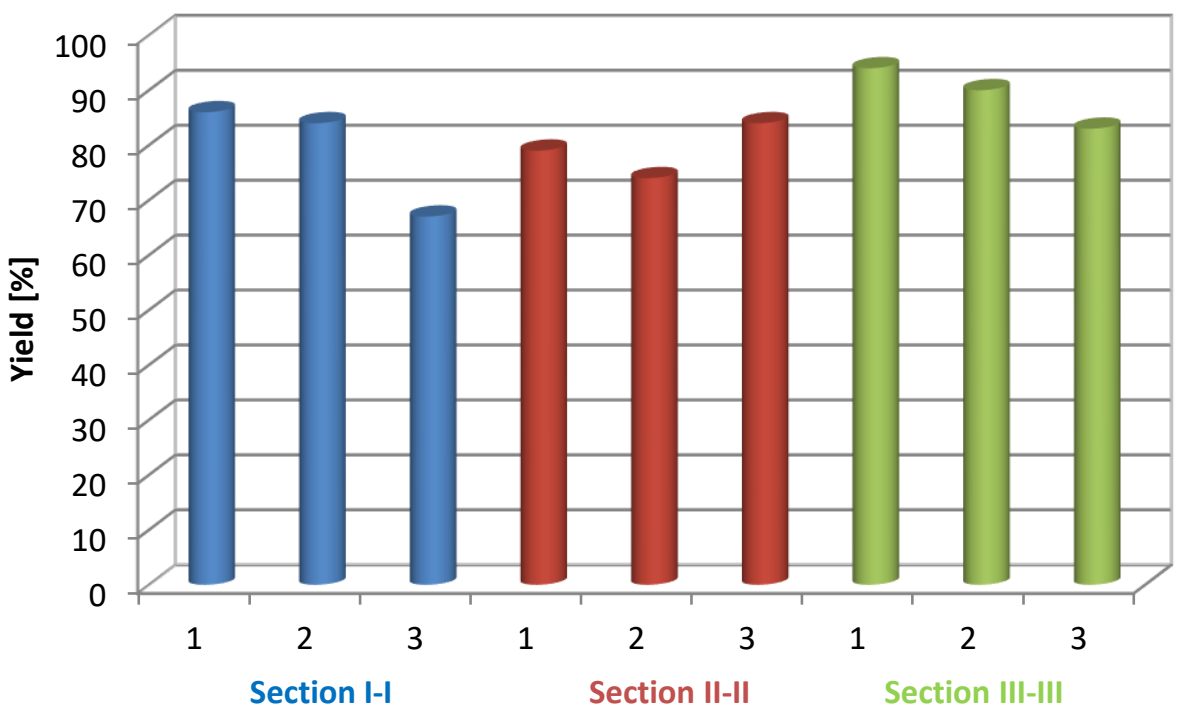

Fig. 4 Depollution yield

Yields obtained in a relatively short time ( 3 months) are considerably higher than those obtained by Lecomte (1998): 60-73\% - 7 months $^{19}$, Gogoi et al. (2003): $75 \%-12$ months $^{25}$ and Chemlal et al. (2012): $70 \%-40$ days ${ }^{30}$.

Results can be compared to results obtained by adding natural gums: 82\% (Hernández-Espriú et al. 2013) or through combined processes: vermiremediation (Pontoscolex corethrurus) + bioaugmentation (86\%) and phytoremediation (Panicum maximum) + vermiremediation (Pontoscolex corethrurus) + bioaugmentation $(82.7 \%)^{37}$.

The results are much better than results obtained by natural degradation using plants: Wheat (Triticum aestivum L.) and field peas (Pisum sativum L.), $(46-53 \%)^{35}$ or by adding microorganisms belonging to genera Rhodococcus-55-59\% ${ }^{34}$; Streptomyces sp. Hlh1-40\% $\%^{36}$ and Acinetobacter SZ-1-34 \% $\%^{31}$. The obtained results support the claims of Cerquira et al. (2011) and Suja et al. (2014) according to which indigenous microbial strains are recommended for use in the bioremediation process ${ }^{26,27}$.

\section{Conclusions}

All samples show a pronounced decrease in the concentration of TPH after only two weeks of treatment, regardless of the sampling point or depth. At the end of the experiment period (12 weeks) it can be observed that the value of pollutant concentration has decreased below $1000 \mathrm{mgkg}^{-1}$.

During the experiment there was an increase in the number of microorganisms from $102 \times 10^{5}-209 \times 10^{5}$ to $127 \times 10^{7}-238 \times 10^{7} \mathrm{CFU} / \mathrm{g}$ of soil, which led to a significant decrease of TPH.

Results obtained on the pilot scale model showed a depollution efficiency between $64-94 \%$, the average efficiency being $83 \%$. Yields obtained in the pilot scale experiment, under shorter treatment time, are comparable or even higher than yields obtained by other researchers.

Following the analysis performed on the model at the pilot scale regarding the depollution process, it can be concluded that a soil contaminated with petroleum hydrocarbons can be efficiently depolluted by performing an aeration of $8 \mathrm{~h} /$ day, adding microorganisms Pseudomonas and Bacillus to ensure the conditions for increasing in the total number of germs (colony forming units-CFU) from $151 \times 10^{5}$ to $213 \times 10^{7} \mathrm{CFU} / \mathrm{gram}$ of soil, after 12 weeks of soil treatment-the depollution efficiency achieved is $83 \%$.

\section{Acknowledgements}




\section{References}

1. Bastida, F. et al. The ecological and physiological responses of the microbial community from a semiarid soil to hydrocarbon contamination and its bioremediation using compost amendment. J. Proteomics. 135, $162-$ 169 (2016).

2. Dunea, A., Dunea, D. Real applications of mathematical modelling in energy-environment interaction processes. National Conference of Biotechnology and Environmental Engineering Târgovişte, Ed. Macarie (in romanian) (2000).

3. Zhou, Q., Cai, Z., Zhang, Z., Liu, W. Ecological Remediation of Hydrocarbon Contaminated Soils with Weed Plant. J. Resour. Ecol. 2(2), 97-105 (2011).

4. Adegbola, G.M., Eniola, K.I.T., Opasola, O.A. Isolation and identification of indigenous hydrocarbon tolerant bacteria from soil contaminated with used engine oil in Ogbomoso, Nigeria. Adv. App. Sci. Res. 5(3), 420422 (2014).

5. Miclean, M. et al. Determination of total petroleum hydrocarbons in contaminated soil by FTIR and GCFID methods. Studia Universitatis Babes-Bolyai Chemia 55(3), 83-91 (2010).

6. Sihag, S., Pathak, H., Jaroli, D.P. Factors Affecting the Rate of Biodegradation of Polyaromatic Hydrocarbons. Int. J. Pure App. Biosci. 2(3), 185-202 (2014).

7. Buzmakov, S., Egorova, D., Gatina, E. Effects of crude oil contamination on soils of the Ural region, $J$ Soils and Sediments. 19, 38-48; 10.1007/s11368-018-2025-0 (2019).

8. Ward, O.P., Singh, A., Van Hamme, J. Accelerated biodegradation of petroleum hydrocarbon waste. J. Int. Microbiol. Biotechnol. 30, 260-270 (2003).

9. Rogers, J.E. Soil bioremediation: review of land treatment and composting options. Land Contam. Reclam. 6, 215-222 (1998).

10. Sinke, A., Hecho, I. Monitored Natural Attenuation: Review of existing guidelines and protocols. TNONicole report TNO-MEP R99/313. TNO Institute of Environmental Science, Energy Research and Process Inovatin, Apeldoom. (1999).

11. Khan, F.I., Husain, T., Hejazi, R. An overview and analysis of site remediation technologies. J Environ Manage. 71, 95-122 (2004).

12. Velea, L.M., Popovici, D., Popovici, O., Podea, Z. Measurement and Control Systems with Programmable SMC- PLC Automation Systems, Conference Proceedings of The National Symposium of Theoretical Electrical Engineering SNET 09, Bucharest (2009).

13. Megharaj, M., Ramakrishnan, B., Venkateswarlu, K., Sethunathan, N., Naidu, R. Bioremediation approaches for organic pollutants: A critical perspective. Environ. Int. 37, 1362-1375, doi:10.1016/j.envint.2011.06.003 (2011).

14. Iturbe, R., López, J. Bioremediation for a Soil Contaminated with Hydrocarbons. J. Pet. Environ. Biotechnol. 6, 208 (2015).

15. Das, N., Chandran, P. Microbial degradation of petroleum hydrocarbon contaminants: an overview. Biotechnol. Res. Int. 11, 1-13 (2011).

16. Agnello, A.C., Bagard, M., van Hullebusch, E.D., Esposito, G., Huguenot, D. Comparative bioremediation of heavy metals and petroleum hydrocarbons co-contaminated soil by natural attenuation, phytoremediation, bioaugmentation and bioaugmentation-assisted phytoremediation. Sci. Total Environ. 563-564, 693-703 (2016).

17. Chiu, H.Y., Verpoort, F., Liu, J.K., Chang, Y.M., Kao, C.M. Using intrinsic bioremediation for petroleum-hydrocarbon contaminated groundwater cleanup and migration containment: Effectiveness and mechanism evaluation. J. Taiwan Inst. Chem. Eng. 72, 53-61 (2017).

18. Potra, A.F., Micle, V., Băbut, C.S. Bioremediation of Petroleum Hydrocarbon-Contaminated Soil by Composting Technology. ProEnvironment/ProMediu. 6(14), 411-415 (2013).

19. Lecomte, P. Les sites pollués - traitement des sol set des eaux souterraunes (ed. Lavoisier), New York (1998).

20. Urs (Nedelcu), A.M., Micle, V., Berar (Sur), I.M. Study on Mathematical Modelling of the Aeration and Irrigation Processes in Case of Biological Decontamination of Soils through Biopile Method. ProEnvironment/ProMediu. 4(8), 212-216 (2011). 
21. Urs, A.M., Micle, V., Berar (Sur), I.M. Studies on polluted soil aeration systems to improve efficiency of soil remediation using biopile technology. ProEnvironment/ProMediu. 3(6), 437-441 (2010).

22. Iturbe, R., Flores, C., Chavez, C., Bautista, G., Torres, G. Remediation of contaminated soil using Soil Washing and Biopile methodologies at a field level. J Soils and Sediments. 4(2), 115-122; 10.1007/BF02991055 (2004).

23. Iturbe, R., Flores, C., Torres, L.G. Operation of a $27 \mathrm{~m}^{3}$ biopile for the treatment of petroleumcontaminated soil. Remediation Journal. 17(2), 97 - 108; 10.1002/rem.20126 (2007).

24. Seklemova, E., Pavlova, A., Kovacheva, K. Biostimulation-Based Bioremediation of Diesel Fuel: Field Demonstration. Biodegradation. 12(5), 311-316 (2011).

25. Gogoi, B.K., Dutta, N.N., Goswami, P., Krishna Mohan, T.R. A case study of bioremediation of petroleum-hydrocarbon contaminated soil at a crude oil spill site, Adv Environ Res. 7(4), 767-782; 10.1016/S10930191(02)00029-1 (2003).

26. Cerqueira, V.S. et al. Biodegradation potential of oily sludge by pure and mixed bacterial cultures. Bioresour. Technol. 102, 11003-11010 (2011).

27. Suja, F. et al. Effects of local microbial bioaugmentation and biostimulation on the bioremediation of total petroleum hydrocarbons (TPH) in crude oil contaminated soil based on laboratory and field observations. Int. Biodeter. Biodegr. 90,115-122 (2014).

28. Baldan, E., Basaglia, M., Fontana, F., Casella, S. Development, assessment and evaluation of a biopile for hydrocarbons soil remediation. Int. Biodeter. Biodegr. 98, 66-72 (2015).

29. Ma, J., et al. Effects of adding bulking agent, inorganic nutrient and microbial inocula on biopile treatment for oil-field drilling waste. Chemosphere 150, 17-23 (2016).

30. Chemlal, R., Tassist, A., Drouiche, M., Lounici, H., Drouiche, N., Mameri, N. Microbiological aspects study of bioremediation of diesel-contaminated soils by biopile technique. Int. Biodeter. Biodegr. 75, 201-206 (2012).

31. Wu, M., et al. Bioaugmentation and biostimulation of hydrocarbon degradation and the microbial community in a petroleum-contaminated soil. Int. Biodeter. Biodegr. 107, 158-164 (2016).

32. Akbari, A., Ghoshal, S. Pilot-scale bioremediation of a petroleum hydrocarbon-contaminated clayey soil from a sub-Arctic site. J Hazard Matter. 280, 595-602; 10.1016/j.jhazmat.2014.08.016 (2017).

33. Hernández-Espriú, A., Sánchez-León, E., Martínez-Santos, P., Torres, P.G. Remediation of a dieselcontaminated soil from a pipeline accidental spill: enhanced biodegradation and soil washing processes using natural gums and surfactants. J Soils Sediments. 13, 152-165, DOI 10.1007/s11368-012-0599-5 (2013).

34. Puntus, I.F. et al. Contribution of soil bacteria isolated from different regions into crude oil and oil product degradation. J Soils and Sediments. 19, 3166-3177; 10.1007/s11368-018-2003-6 (2019).

35. O’Brien, P.L., DeSutter, T.M., Casey, F.X.M. Natural degradation of low-level petroleum hydrocarbon contamination under crop management. J Soils and Sediments. 19, 1367-1373; 10.1007/S11368-018-2153-6 (2019).

36. Baoune, H., Aparicio. J.D., Pucci, G., Ould, El., Hadj-Khelil, A., Polti, M.A. Bioremediation of petroleum-contaminated soils using Streptomyces sp. Hlh. J Soils and Sediments. 19, 2222-2230; 10.1007/s11368019-02259-w (2019).

37. Rodriguez-Campos, J., Perales-Garcia, A., Hernandez-Carballo, J., Martinez-Rabelo, F., HernándezCastellanos, B., Barois, I., Contreras-Ramos, S.M. Bioremediation of soil contaminated by hydrocarbons with the combination of three technologies: bioaugmentation, phytoremediation, and vermiremediation. $J$ Soils and Sediments. 19, 1981-1994; 10.1007/s11368-018-2213-y (2019).

38. Micle, V. et al. Lab-scale experimental investigation concerning ex-situ bioremediation of petroleum hydrocarbons contaminated soils. Soil and Sediment Contamination: An International Journal. 27(8), 692-705; 10.1080/15320383.2018.1503229 (2018).

39. ICPA (1987) Methodology for working up pedological studies, Part III - Eco- pedological indexes, National Research and Development Institute for Soil Science Agro-Chemistry and Environment, Bucureşti, Romania (in romanian). (1987).

40. Senila, M., Levei, E.A., Senila, L.R., Oprea, G.M., Roman, C.M. Mercury in soil and perennial plants in a miningaffected urban area from Northwestern Romania. J. Environ. Sci. Health Pt. A. 47, 614-621 (2012).

41.SR EN ISO 11274:2020. Soil quality. Determination of water retention characteristic. Laboratory methods. (2020). 
42. Bahemmat, M., Farahbakhsh, M., Kianirad, M. Humic substances-enhanced electroremediation of heavy metals contaminated soil. J. Hazard Mater. 312, 307-318; 10.1016/j. jhazmat.2016.03.038 (2016).

43. Order No. 756 of November 3, 1997 for the Approval of the Regulation on Environmental Pollution Assessment. Eminent: Ministry of Waters, Forests and Environmental Protection. (Published in: Official Gazette No 303 bis of 6 November 1997) (in romanian); http://legislatie.just.ro/Public/DetaliiDocumentAfis/151788. (1997).

44. Micle, V., Sur, I.M., Mitrea, M. Patent application: Ex-situ bioremediation process of hydrocarbon polluted soils using Pseudomonas and Bacillus microorganisms. Official Bulletin of Industrial Property (OSIM) 
Figures

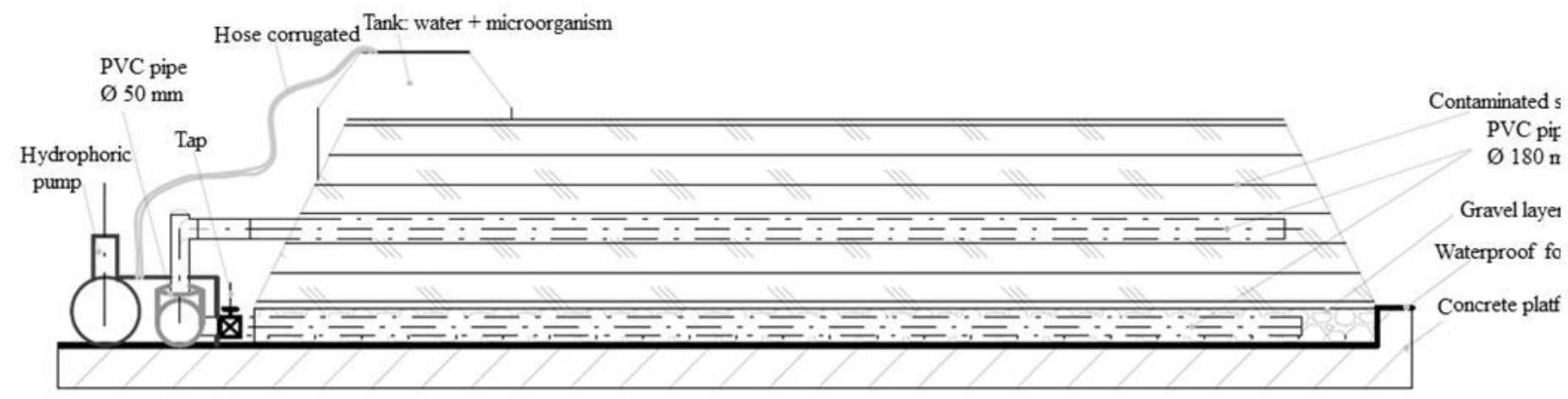

Figure 1

Pilot scale experiment

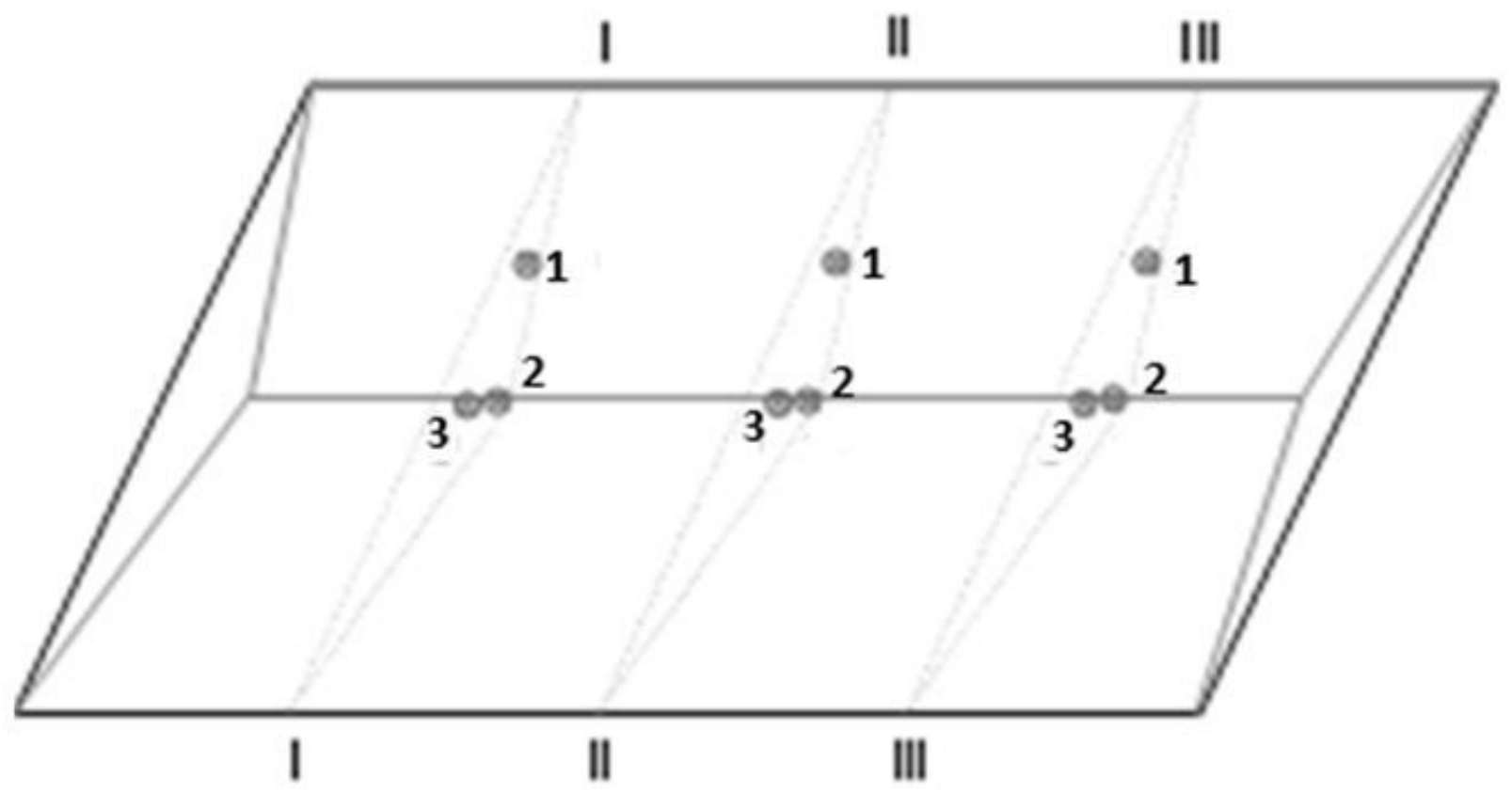

Figure 2

Soil sampling scheme 


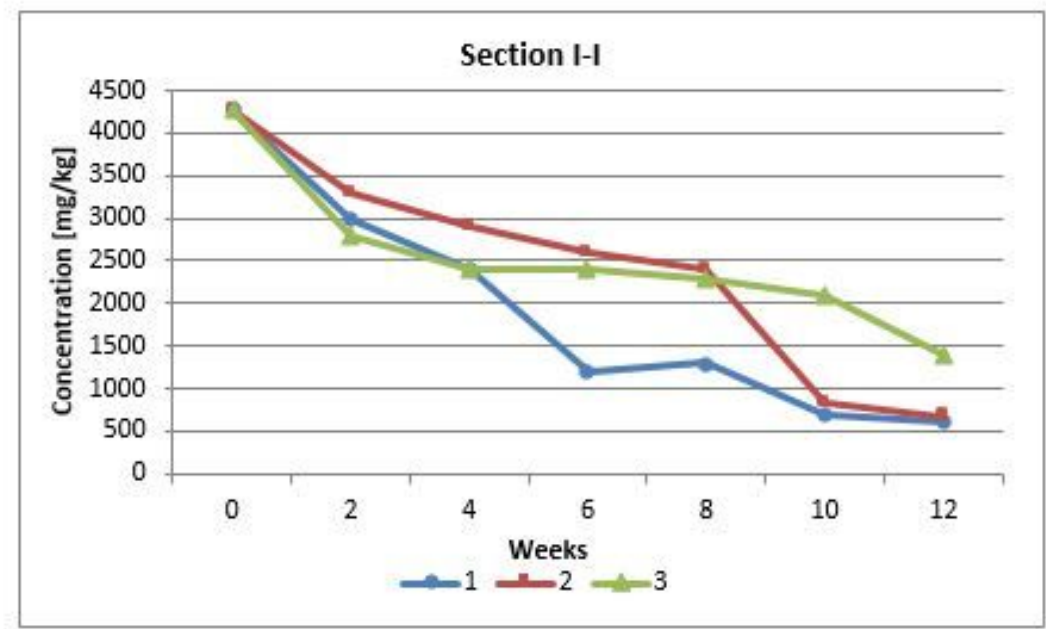

a)

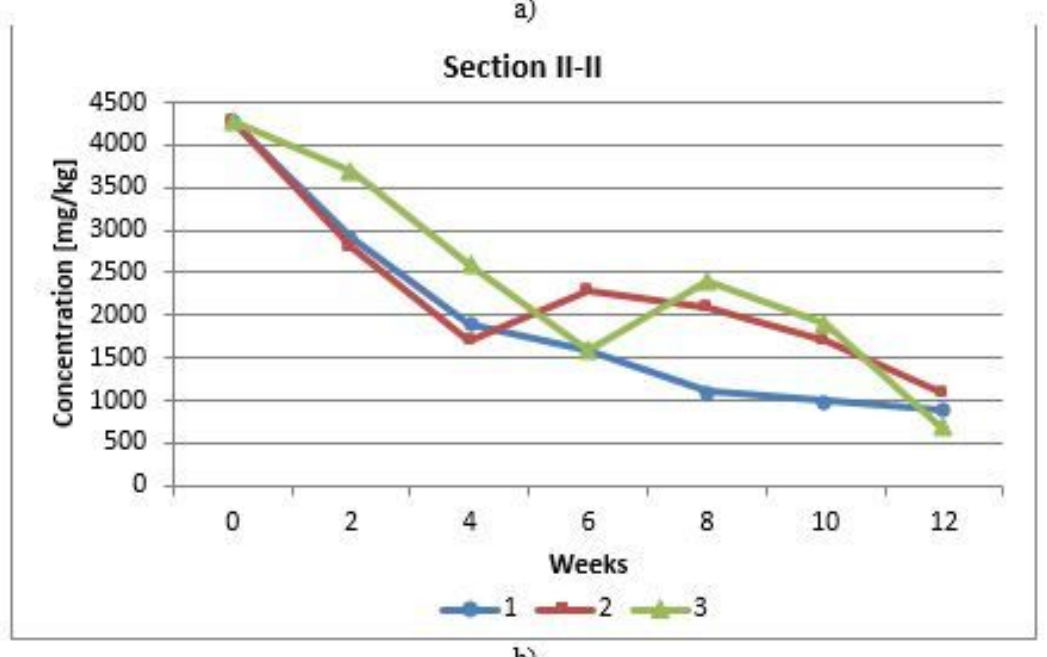

b)

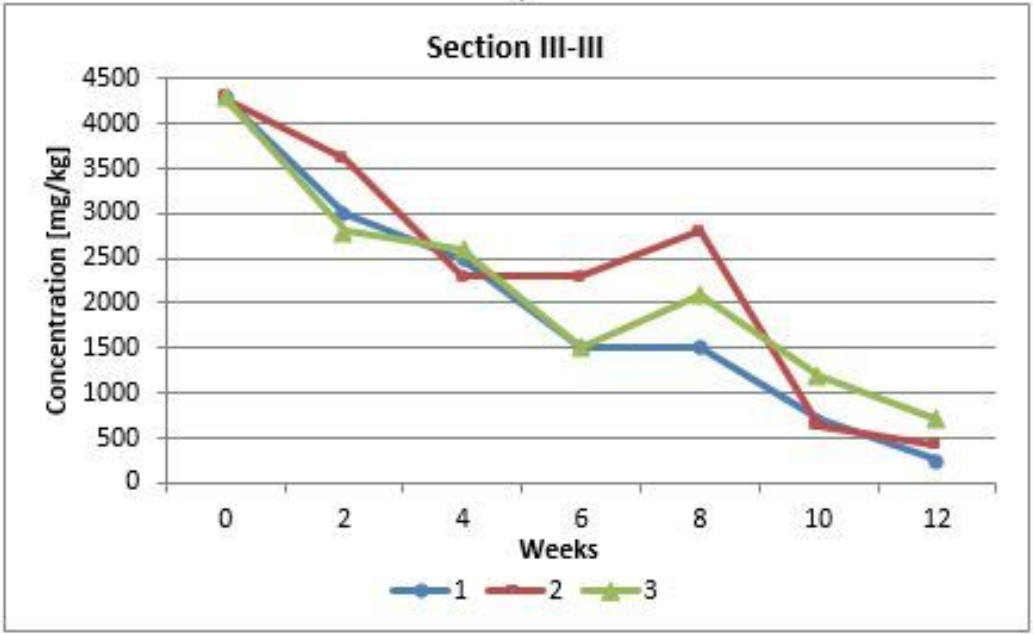

c)

Figure 3

PHC concentration depending on time and section: a) section $\mathrm{H}$; b) section II-II; c) section III-III 


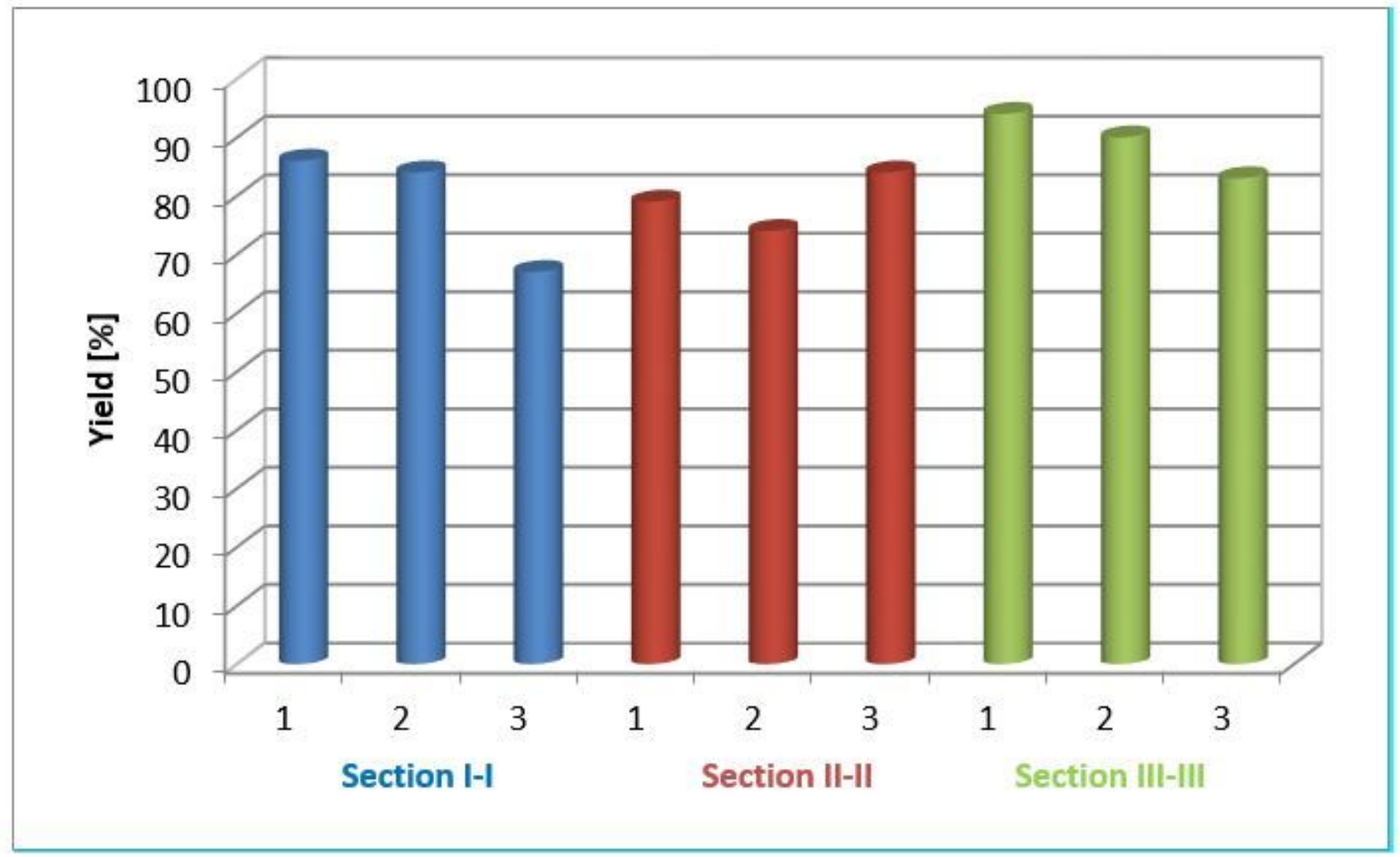

Figure 4

Depollution yield 